\title{
PEMANFAATAN LIMBAH RUMAH TANGGA SEBAGAI KOMPOS PADA TANAMAN BAWANG MERAH (ALLIUM CEPA VAR. AGREGATUM L.)
}

\section{Utilization of Household Wasteas Compost on Shallot (Allium cepa var. Agregatum L.)}

\author{
Janet M. Mabel, Sumiyati Tuhuteru* \\ Program Studi Agroteknologi, Sekolah Tinggi Ilmu Pertanian Petra Baliem Wamena \\ e-mail: *sumiyati.tuhuteru@yahoo.com
}

\begin{abstract}
ABSTRAK
Sistem pertanian yang diterapkan di Wamena merupakan sistem pertanian organik yang berbasis pemanfaatan pupuk kandang saja. Penggunaan pupuk hayati maupun kompos masih sangat minim dilakukan. Budidaya tanaman bawang merah secara organik yang ramah lingkungan merupakan salah satu solusi terhadap bahaya penggunaan pupuk kimia dan pestisida sintetik yang berlebihan dalam hal ini pemakaiannya terus menerus. Tujuan penelitian ini adalah untuk mengetahui respon pertumbuhan dan hasil tanaman bawang merah dengan pemanfaatan kompos berbahan dasar limbah rumah tangga. Penelitian dilaksanakan di Distrik Walelagama Kota Wamena, dilanjutkan di Laboratorium di Laboratorium Sekolah Tinggi Ilmu Pertanian Petra Baliem Wamena. Penelitian dirancang dengan rancangan percobaan Rancangan Acak Kelompok (RAK) yang terdiri atas 3 taraf yakni tanpa perlakuan (Kontrol), Perlakuan pupuk kompos 50 gr kompos/polybag, dan perlakuan 100 gr kompos/polybag. Hasil pengamatan dianalisis dengan uji F dan dilanjutkan dengan uji BNT (Beda Nyata Terkecil) pada taraf 5\%. Hasil penelitian menunjukkan pemberian kompos berbahan dasar limbah rumah tanggah yang menggunakan aktivator MOL dan EM4 memberikan pengaruh nyata terhadap pertumbuhan dan produksi bawang merah yang terbaik adalah 50 gr kompos/polybag yakni pada parameter tinggi tanaman dan jumlah daun, dan 100 gr kompos/polybag pada parameter bobot segar umbi dan bobot keringangin umbi.
\end{abstract}

Kata kunci: Bawang Merah, Kompos, Limbah Rumah Tangga.

\section{ABSTRACT}

The farming system implemented in Wamena is an organic farming system based on use of manure. The use of biological fertilizer and compost is still very minimal. Organic shallot cultivation that is environmentally friendly is one solution to the dangers of using chemical fertilizers and synthetic pesticides, in this case continuous use. The purpose of this study was to determine the response of the growth and yield of shallots with using of compost from household waste. The research was carried out in Walelagama District of Wamena City, continued at Laboratory of Agriculture, Collage of Agriculture Petra Baliem Wamena. The study was designed with a randomized block design consisting of 3 levels namely without treatment (Control), treatment of $50 \mathrm{gr}$ compost/polybag, and treatment of $100 \mathrm{gr}$ compost/polybag. The observations were analyzed with the F-test and continued with the LSD test (Least Significant Difference) 5\% level. The results showed that the provision of compost from household waste using MOL and EM4 activators had a significant effect on growth and yield of shallots, 
Agritrop, Vol. 18 (1): 51 - 59

treatment of 50 grams is an the best treatment namely on plant height and leaf number parameters, and treatment of $100 \mathrm{gr}$ of compost/polybag is an the best treatment for the parameters of fresh weight of bulbs and bulb dry weight.

Keywords: Compost, Household Wasteas, Shallot

\section{PENDAHULUAN}

Bawang merah merupakan komoditas sayuran unggulan yang sudah sejak lama telah diusahakan oleh petani secara intensif. Bawang merah tersebar hampir di seluruh wilayah Indonesia (Tuhuteru et al. 2016). Bawang merah merupakan komoditas sayuran berpotensi untuk dikembangkan guna meningkatkan pendapatan petani. Kemampuan produksi budidaya masih belum mampu memenuhi permintaan pasar dalam negri yang terus meningkat. Tingginya permintaan bawang merah tidak di iringi dengan prosuksi bawang merah yang stabil. Produksi bawang merah di Indonesia terus mengalami fluktuasi. Produksi bawang merah hadir tahun 2010 sampai 2014 berturut-turut yaitu 1.048.934 ton, 893.124 ton, 964.221 ton, 1.010.773 ton dan 1.233.989 ton. Sedangkan pada tahun 2016 produksi bawang merah mencapai 1.446 .860 ton. Berbagai upaya terus dilakukan untuk meningkatkan produksivitas tanaman bawang merah. Terutama untuk meningkatkan potensi lokal bawang merah pada pertanian di iklim basah tropis seperti wamena. Wamena memiliki satu varietas lokal bawang merah yang sudah dikenal oleh masyarakat sekitar, yang sering di budidayakan petani di beberapa Distrik di Wamena dan perlu untuk dikembangkan.

Sejauh ini, sistem pertanian yang diterapkan di Wamena merupakan sistem pertanian organik yang berbasis pemanfaatan pupuk kandang semata. Penggunaan pupuk hayati maupun kompos masih sangat minim dilakukan. Budidaya tanaman bawang merah secara organik yang ramah lingkungan merupakan salah satu solusi terhadap bahaya penggunaan pupuk kimia dan pestisida sintetik yang berlebihan dalam hal ini pemakaiannya terus menerus. Pertanian organik muncul sebagai salah satu alternatif pertanian modern dengan mengandalkan bahan alami dan menghindari bahan sintetik, baik pupuk maupun pestisida (Soenandar dan Tjachjono, 2012).

Pemanfaatan bahan organik tanah sejauh ini dilakukan dengan penambahan pupuk kandang semata atau dengan sistem pertanian lahan berpindah. Untuk itu diperlukan penerapan pemanfaatan pupuk organik lainnya dalam budidaya tanaman di Wamena. Upaya untuk menigkatkan produksi tanaman bawang merah antara lain dengan perbaikan sistem budidaya misalnya penerapan pertanian organik berkelanjutan, seperti pemanfaatan pupuk kompos limbah rumah tangga, yang diketahui dapat menjadi sumber unsur hara bagi tanaman.

Pupuk organik dari kompos sangat bermanfaat bagi peningkatan produksi pertanian baik kualitas maupun kuantitas, mengurangi pencemaran lingkungan, dan meningkatkan kualitas lahan yang berkelanjutan. Pupuk organik dapat memperbaiki struktur tanah yang semula padat menjadi gembur, tanah berpasir menjadi lebih kompak, dan tanah lempung menjadi gembur. Selain itu, pembuatan sampah organik menjadi kompos dapat mengurangi permasalahan sampah secara umum di perkotaan dan lingkungan sekitar karena menumpuknya sampah. Kompos yang dibuat dari sampah organik di rumah tangga dapat digunakan sebagai pupuk organik untuk sayuran yang ditanam di pekarangan rumah.

Limbah hasil aktivitas manusia merupakan permasalahan klasik pada setiap wilayah, mulai dari tingkat desa sampai kota, terutama dari segi lingkungan, kesehatan, keindahan, serta estetika. Setiap aktivitas yang dilakukan oleh manusia mulai dari rumah tangga sampai industri hampir selalu menghasilkan limbah, baik limbah anorganik maupun organik. Pemanfaatan limbah rumah tangga merupakan upaya/kegiatan yang sejalan dengan Rencana Kerja Kementerian Pertanian Tahun 2018, yakni pengembangan infrastruktur dan penguatan investasi 
Agritrop, Vol. 18 (1): 51 - 59

untuk percepatan peningkatan produksi dan ekspor pangan melalui salah satu kebijakan operasionalnya yakni percepatan pengembangan pertanian organik. Salah satu alternatif untuk mempertahankan dan meningkatkan hasil tanaman bawang merah adalah dengan cara pemberian pupuk organik.

Pupuk organik kompos limbah rumah tangga tidak menimbulkan efek buruk bagi kesehatan tanaman karena bahan dasarnya alamiah, sehingga mudah diserap secara menyeluruh oleh tanaman. Selain itu, kompos merupakan olahan sisa bahan organik yang berasal dari tanaman, hewan, dan limbah organik yang telah mengalami proses dekomposisi atau fermentasi, yang dapat dipercepat dengan bantuan manusia dengan penambahan mikroorganisme yang dapat mempercepat fermentasi (Soenandar dan Tjachjono, 2012). Pengomposan menurut Djuarnani et al. 2005 merupakan proses dekomposisi terkendali secara biologis terhadap sampah padat organik dalam kondisi aerobik (terdapat oksigen) atau anaerobik (tanpa oksigen). Pupuk kompos mengandung unsur hara mikro dan makro esensial (N, P, K, S, Mg, B, Mo, Cu, Fe, Mn, dan bahan organik). Selain unsur hara, pupuk kompos juga mengandung mikroorganisme yang terdapat dalam tanah misalnya azotobacter sp, azospinillum sp, lactobacillus $s p$, mikroba pelarut phosphor dan mikroba selutolik (Ersa, 2018).

Pupuk kompos mempunyai banyak manfaat di antaranya dapat mendorong dan menigkatkan bembentukan klorofil daun dan pembentukan bintil akar pada tanaman leguminosa sehingga meningkatkan kemampuan fotosintesis tanaman dan menyerap nitrogen dari udara (Yusuf, 2010). Untuk itu, penelitian ini bertujuan untuk mengetahui respon pertumbuhan dan hasil tanaman bawang merah dengan pemanfaatan kompos berbahan dasar limbah rumah tangga.

\section{METODE PENELITIAN}

Bahan penelitian yang digunakan adalah sampah organik rumah tangga yang berasal dari pengumpulan sampah di Distrik Walelagama Kota Wamena, sisa sisa makanan, sayuran, air bersih, aktivator EM4, MOL, dedak. Sedangkan peralatan yang digunakan: timbangan, sprayer, ember, sekop, ayakan, pH meter dan peralatan untuk analisa bahan baku sampah organik dan produk kompos. Penelitian disusun menggunakan metode Rancangan Acak Kelompok (RAK) yang terdiri atas 3 konsentrasi yakni tanpa perlakuan (Kontrol), Perlakuan $50 \mathrm{gr}$ kompos/polybag, dan perlakuan 100 gr kompos/polybag. Perlakuan di ulang sebanyak 3x hingga terdapat 9 total perlakuan dan masing-masing perlakuan terdiri dari 5 tanaman, sehingga terdapat 40 polybag dalam 1 unit percobaan, dimana masing-masing perlakuan memiliki 3 tanaman sampel, sehingga terdapat 27 tanaman sampel. Data hasil pengamatan dianalisis dengan uji $\mathrm{F}$ dan di lanjutkan dengan uji BNT (Beda Nyata Terkecil) pada taraf 5\%.

Langkah dalam pelaksanaan penelitian ini adalah : terlebih dahulu membuat larutan aktivator Mol, yakni dengan cara menyiapkan bahan seperti tapai singkong, gula merah, dan air bekas cucian beras, mencampur bahan-bahan tersebut kemudian dilakukan fermentasi aerob selama 4 - 5 hari, menyimpan MOL sebagai biang MOL, bila akan digunakan dilakukan perbanyakan MOL, dengan membagi dua bagian biang mol, tambahkan air cucian beras dan gula merah (Isro'i, 2010). Penambahan kombinasi aktrivator EM4 dan MOL dengan perbandingan $2: 1$.

Sebelum umbi bawang ditanam, terlebih dahulu diberikan perlakuan pemberian kompos yang sudah dibuat pada masing-masing polybag sesuai dengan perlakuan yang telah ditetapkan. Penanaman di lakukan dengan cara membuat lubang tanam pada masing-masing polybag yang telah diberi pelakuan. Umbi di potong 1/3 bagian, kemudian di masukan ke dalam lubang tanah dengan kedalaman $\pm 7 \mathrm{~cm}$. selanjutnya dibenamkan. 
Agritrop, Vol. 18 (1): 51 - 59

\section{Pembuatan Kompos Limbah Rumah Tangga}

Langkah-langkah pembuatan kompos berbahan dasar limbah rumah tangga adalah sebagai berikut: mengumpulkan sampah organik dari sumber yang sama dari hasil karakterisasi sampah organik rumah tangga. Kemudian dicacah hingga berukuran 2-3 $\mathrm{mm}$, kemudian seluruhnya dicampur dengan dedak secara merata Tambahkan larutan aktivator EM4 dan MOL dengan cara disemprotkan dan diaduk supaya homogen. Melakukan fermentasi selama 4 minggu dengan diaduk-aduk setiap 3 hari. Pengomposan dihentikan saat kompos terlihat matang dengan parameter yang terlihat dari warna, tekstur, bau, suhu kompos, dan pH (Djuarnani, 2005; Yuwono,2005). berdasarkan perlakuan yang telah ditetapkan, yakni:

- K0: tanpa perlakuan (Kontrol),

- K1: 50 gr kompos/polybag,

- K3: 100 gr kompos/polybag.

Tahapan selanjutnya setelah penanaman umbi bawang merah adalah proses pemeliharaan tanaman yang meliputi:

a. Penyiraman; Penyiraman dilakukan dengan menggunakan gembor pada pagi dan sore hari dan disesuaikan dengan kondisi lingkungan tempat penelitian. Penyiraman dengan selang waktu dua kali sehari, yakni pada pagi dan sore hari. Namun, hanya dilakukan apabila media tumbuh terlihat mulai kering.

b. Penyiangan gulma; Proses penyiangan dilakuan setiap saat, dengan mencabut setiap rumput atau tanaman pengganggu yang tumbuh disekitar area penanaman. Hal ini bertujuan untuk menghindari adanya persaingan dalam menyerap unsur hara yang terkandung dalam tanah dan terkait penerimaan pencahayaan matahari.

Pengamatan yang dilakukan pada penelitian ini meliputi pengamatan pertumbuhan meliputi tinggi tanaman dan jumlah daun yang diamati pada 3, 5 dan 7 MST dan pengamatan panen meliputi bobot segar umbi panen dan bobot kering umbi yang diamati pada 9 MST. Data hasil penelitian dianalisis dengan Analisis varians (ANOVA). Selanjutnya untuk mengetahui perlakuan yang berbeda nyata dilanjutkan dengan Uji Beda Nyata Terkecil (BNT) pada taraf 5 $\%$.

\section{HASIL DAN PEMBAHASAN}

Hasil analisis ragam untuk parameter pertumbuhan tanaman yang diamati menunjukan pengaruh nyata, baik pada parameter tinggi tanaman maupun parameter jumlah daun tanaman. Hasil penelitian parameter tinggi tanaman pada pengamatan 3,5 dan 7 minggu setelah tanam (MST) berpengaruh nyata yang ditunjukkan oleh perlakuan $50 \mathrm{gr}$ kompos/polybag dengan rerata sebesar 24,93 cm (pengamatan 3 MST), 27,70 cm (pengamatan 5 MST) dan 29,00 cm (pengamatan 7 MST) yang berpengaruh nyata terhadap tanaman kontrol (tanpa perlakuan), namun tidak berpengaruh nyata dengan perlakuan 100 gr kompos/polybag. Hal yang sama juga ditunjukkan pada parameter jumlah daun dengan jumlah rerata sebesar 33,89 helai (pengamatan 3 MST), 36,00 helai (pengamatan 5 MST) dan 37,40 helai (pengamatan 7 MST) yang berbeda nyata dengan tanaman tanpa perlakuan (kontrol) dan tidak berbeda nyata dengan perlakuan penambahan 100 gr kompos/polybag. Hasil analisis parameter penelitian tanaman bawang merah dapat dilihat pada tabel 1 . 
Agritrop, Vol. 18 (1): 51 - 59

Berdasarkan hasil analisis sidik ragam tersebut, dapat dikatakan bahwa pemberian pupuk kompos memberikan sumbangsih pemenuhan akan unsur hara yang di butuhkan oleh tanaman itu sendiri. Baik unsur hara makro maupun mikro, yang berperan penting dalam pertumbuhan tanaman. Seperti kandungan N yang diduga bertambah akibat adanya peningkatan aktivitas mikroorganisme tanah. Poerwowidodo (1992), menjelaskan bahwa tanaman yang tidak mendapat unsur $\mathrm{N}$ akan tumbuh kerdil serta daun yang terbentuk lebih kecil, tipis dan jumlahnya sedikit, namun jika yang mendapatkan unsur $\mathrm{N}$ tumbuh lebih tinggi dan daun yang terbentuk lebih banyak dan lebar (Susanti Diana S. 2015).

Diketahui bahwa pembuatan pupuk kompos pada penelitian ini dilakukan dengan bantuan mikroba yang dijadikan sebagai bioaktivator kompos dalam hal ini adalah MOL dan EM4. Sehingga diduga bahwa perlakuan pupuk kompos menyediakan unsur hara yang cukup bagi tanaman untuk melangsungkan pertumbuhan tanaman. Pertumbuhan tanaman merupakan suatu proses yang ditandai dengan bertambahnya ukuran dan berat tanaman. Penambahan ini disebabkan oleh bertambahnya ukuran organ tanaman akibat proses metabolisme yang selain dipengaruhi oleh faktor genetik tanaman juga dipengaruhi oleh faktor lingkungan tumbuh seperti suhu, sinar matahari, air dan nutrisi dalam tanah (Yuliarta, 2014).

Meningkatnya pertumbuhan bawang merah diduga disebabkan oleh unsur hara yang terkandung dalam pupuk kompos mampu meningkatkan kesuburan tanah, aktivitas mikroba tanah serta ketersediaan hara di dalam tanah, terutama dengan penambahan aktivator EM4 yang berperan aktif dalam menyediakan bahan organik tanah melalui aktivitas mikroorganisme tanah. Bahan organik akan diubah hingga menyerupai tanah. Pemberian pupuk kompos dapat memberikan sumbangsih pemenuhan akan unsur hara yang di butuhkan oleh tanaman itu sendiri. Tanaman yang tidak mendapat unsur $\mathrm{N}$ akan tumbuh kerdil serta daun yang terbentuk lebih kecil, tipis dan jumlahnya sedikit, namun jika yang mendapatkan unsur $\mathrm{N}$ tumbuh lebih tinggi dan daun yang terbentuk lebih banyak dan lebar (Poerwowidodo, 1992).

Kondisi terkendali tersebut menurut Mukhlis dan Anggorowati (2011) banyaknya jumlah daun yang terbentuk berarti luas daun menjadi lebih besar, maka kemampuan daun dalam menerima cahaya untuk proses fotosintesis menjadi lebih besar dalam menghasilkan karbohidrat dan akan ditranlokasikan kebagian umbi sehingga mempengaruhi besar dan berat umbi. Widawati et al. (2002) mengemukakan bahwa pemberian bahan organik pada tanah berperan penting dalam memperbaiki struktur tanah sehingga aerasi udara dan pergerakan air lancar, dengan demikian dapat menambah daya serap air dalam tanah dan mampu meningkatkan pertumbuhan dan produksi tanaman. Selanjutnya pemberian pupuk organik mempunyai manfaat untuk meningkatkan jumlah air yang dapat ditahan di dalam tanah dan jumlah air yang tersedia bagi tanaman serta sebagai sumber energi bagi jasad mikro sehingga tanpa adanya pupuk organik semua kegiatan biokimia akan terhenti (Nizar, 2011).

Hal in pun seperti yang dikemukakan oleh Elisabeth et al. 2012, yang menyatakan bahwa peran bahan organik dari aspek tanaman berasal dari hasil pelapukan bahan organik yang diduga dapat mengandung asam organik yang dapat meningkatkan ketersediaan hara bagi tanaman dan dapat diserap tanaman dengan segera. Peningkatan pertumbuhan tanaman dari parameter pertumbuhan yang di amati pada akhirnya berpengaruh terhadap produksi tanaman bawang merah yang dibudidayakan.

Selain berpengaruh nyata pada parameter pertumbuhan, pemberian kompos juga berpengaruh terhadap bobot segar umbi dn bobot keringangin umbi. Hasil penelitian menunjukkan penambahan kompos berpengaruh nyata pada parameter bobot segar umbi dan bobot keringangin umbi yang ditunjukkan oleh perlakuan dengan penambahan 100 gr kompos/polybag, dengan rerata sebesar 23,61 gr bobot segar umbi dan 11,72 gr bobot umbi setelah dikeringanginkan selama 3 hari setelah dipanen, yang berbeda nyata dengan tanaman kontrol (tanpa perlakuan), namun tidak berbeda nyata dengan perlakuan 50 gr kompos/polybag 
Agritrop, Vol. 18 (1): 51 - 59

(Tabel 2). Hal ini menunjukkan bahwa pemberian kompos berbahan dasar limbah rumah tangga memberikan respon positif bagi pertumbuhan dan hasil tanaman bawang merah. Hal ini diduga karena kompos merupakan pupuk organik yang merupakan hasil akhir dari peruraian bagianbagian atau sisa-sisa (serasah) tanaman dan binatang. Diketahui bahwa, pupuk organik bermanfaat untuk menggemburkan lapisan permukaan tanah (top soil), meningkatkan populasi jasad renik, mempertinggi daya serap dan daya simpan air sehingga dapat meningkatkan kesuburan tanah (Ekawandani dan Kusuma, 2018). Selain itu, diketahui bahwa kompos mengandung unsur hara makro dan mikro yang lengkap walaupun dalam jumlah yang sedikit dan berfungi memperbaiki kehidupan mikroorganisme didalam tanah dengan cara menyediakan bahan makanan bagi mikroorganisme tersebut. (Djuarnani, 2005).

Pupuk organik diketahui mempunyai peranan penting dalam mempertahankan kesuburan fisik, kimia, dan biologi tanah. Tanah yang kaya bahan organik bersifat lebih terbuka sehingga aerasi tanah lebih baik dan tidak mudah mengalami pemadatan dibandingkan dengan tanah yang mengandung bahan organik rendah (Susanto, 2002; Sumarni et al, 2012). Selain itu berpangaruh pada produksi yang dihasilkan.

Hasil penelitian menunjukkan pemberian pupuk kompos berbahan dasar limbah rumah tanggah berpengaruh terhadap pertumbuhan dan hasil tanaman bawang merah yang diamati seperti tinggi tanaman, jumlah daun, bobot segar umbi, bobot kering daun dan bobot kering umbi tanaman bawang merah. Sedangkan, parameter bobot segar dan kering daun menunjukkan pengaruh yang nyata ditinjukkan oleh perlakuan kontrol (tanpa perlakuan atau 0 gr/tanaman).

Hasil penelitian tersebut menunjukan bahwa pemberian pupuk kompos berbahan dasar limbah rumah tangga baik untuk pertumbuhan dan hasil tanaman. Kompos merupakan olahan sisa bahan organik yang berasal dari tanaman, hewan, dan limbah organik yang telah mengalami proses dekomposisi atau fermentasi, yang dapat dipercepat dengan bantuan manusia dengan penambahan mikroorganisme yang dapat mempercepat fermentasi (Soenandar dan Tjachjono, 2012). Dimana pembuatan pupuk kompos pada penelitian ini dengan bantuan mikroba yang dijadikan sebagai bioaktivator kompos. Sehingga diduga bahwa perlakuan pupuk kompos dapat menyediakan unsur hara yang cukup bagi tanaman untuk melangsungkan pertumbuhan tanaman.

Jika dilihat dari pengaruh pupuk kompos, analisis sidik ragam menunjukkan bahwa hasil bawang merah pada perlakuan P2 (100 gr/tanaman) memberikan hasil berbeda nyata pada bobot segar dan keringangin umbi panen. Hal ini diduga bahwa pupuk kompos perlakuan memiliki kandungan bahan organik sebagai unsur hara yang cukup memenuhi kebutuhan tanaman dari pada perlakuan kompos P1 (50 gr/tanaman). Peran bahan organik dari aspek tanaman dari hasil pelapukan bahan organik dapat mengandung asam organik dapat meningkatkan ketersediaan hara bagi tanaman dan dapat diserap tanaman dengan segera (Elisabeth, 2012).

Kompos diketahui merupakan hasil penguraian bahan organik oleh mikroorganisme, penguraian ini sebenarnya adalah suatu proses biologis oleh mikroorganisme yang sumber energinya berasal dari limbah organik. Proses biologis ini berjalan secara alami karena mikroorganisme memang membutuhkan energi untuk tetap hidup dan berkembang biak. Hal ini disebabkan karena keberadaan bakteri yang ada dalam ekstrak kompos cukup efektif melanjutkan proses degradasi dan dekomposisi bahan organik (Sulistyaningsih et al. 2007). Ukuran dan jenis bahan baku kompos mempengaruhi cepat atau lambat proses penguraian. Selain itu, kombinasi bahan limbah organik juga menjadi faktor penting dalam proses penguraian. Semakin banyak variasi campuran limbah organik, semakin baik kualitas kompos yang akan dihasilkan (Mulyono, 2014).

Ketersediaan unsur hara (N, P, K) yang terdapat didalam kompos yang mana memberikan respon yang positif terhadap pertumbuhan umbi, yang akan diserap dibawa ke daun untuk diasimilasikan dalam proses fotosintesis. Salah satu hasil fotosintesis ini adalah fruktan, dimana fruktan sangat diperlukan untuk pembentukan umbi (Yetti \& Elitta, 2018). Dimana tanaman 
Agritrop, Vol. 18 (1): 51 - 59

Liliaceae menyimpan fruktan didalam umbi (Salisbury F. B. \& Ross, 1995). Dengan kata lain, kompos mengandung unsur hara yang lengkap yang dibutuhkan bagi pertumbuhan tanaman karena mengandung unsur hara mikro seperti nitrogen, fosfor serta kalium dan unsur mikro seperti kalsium, magnesium dan sulfur yang akan menyumbangkan unsur hara ke tanaman (Kusuma et al. 2013). Hal ini pun selanjutnya berpengaruh pada bobot segar dan bobot keringangin umbi bawang merah. Pertumbuhan tanaman akan optimal jika unsur hara yang dibutuhkan tersedia dalam jumlah dan bentuk sesuai dengan kebutuhan tanaman ${ }^{29}$.

Hal ini telah diduga bahwa dari penambahan unsur hara dari masing-masing jenis bahan kompos jika digabungkan akan menjadi lebih baik dari pada satu jenis bahan kompos. Sebagaimana, hasil penelitian sebelumnya menunjukkan bahwa campuran antara sampah sayur dan feses kambing lebih cepat menjadi kompos dari pada variabel yang lain (Cahaya \& Nugroho, 2008).

Dengan demikian, pupuk organik dari kompos sangat bermanfaat bagi peningkatan produksi pertanian baik kualitas maupun kuantitas, mengurangi pencemaran lingkungan, dan meningkatkan kualitas lahan yang berkelanjutan. Pupuk organik dapat memperbaiki struktur tanah yang semula padat menjadi gembur, tanah berpasir menjadi lebih kompak, dan tanah lempung menjadi gembur. Peranan pupuk organik juga penting pada tanah ialah kemampuannya bereaksi dengan ion logam untuk membentuk senyawa kompleks, ion logam yang bersifat meracuni tanaman serta merugikan penyediaan hara pada tanah seperti al, Fe, dan Mn dapat diperkecil. Kompos banyak mengandung mikroorganisme, dengan ditambahkannya kompos di dalam tanah memacu berkembangnya mikroorganisme dalam tanah, gas $\mathrm{CO}_{2}$ yang dihasilkan mikroorganisme tanah akan dipergunakan untuk fotosintesis tanaman dan menghasilkan hormon-hormon pertumbuhan (Matenggomena, 2013).

Pupuk organik dari kompos sangat bermanfaat bagi peningkatan produksi pertanian baik kualitas maupun kuantitas, mengurangi pencemaran lingkungan, dan meningkatkan kualitas lahan yang berkelanjutan. Pupuk organik dapat memperbaiki struktur tanah yang semula padat menjadi gembur, tanah berpasir menjadi lebih kompak, dan tanah lempung menjadi gembur. Peranan pupuk organik juga penting pada tanah ialah kemampuannya bereaksi dengan ion logam untuk membentuk senyawa kompleks, ion logam yang bersifat meracuni tanaman serta merugikan penyediaan hara pada tanah seperti al, Fe, dan Mn dapat diperkecil. Kompos banyak mengandung mikroorganisme, dengan ditambahkannya kompos di dalam tanah memacu berkembangnya mikroorganisme dalam tanah, gas $\mathrm{CO}_{2}$ yang dihasilkan mikroorganisme tanah akan dipergunakan untuk fotosintesis tanaman dan menghasilkan hormon-hormon pertumbuhan yang berperan penting dalam meningkatkan produktivitas tanaman.

Tabel 1. Rerata Tinggi Tanaman (cm) dan Jumlah Daun Bawang Merah (Helai) pada Pengamatan 3, 5 dan 7 MST

\begin{tabular}{ccccccc}
\hline \multirow{2}{*}{ Perlakuan } & \multicolumn{3}{c}{ Tinggi Tanaman (cm/) } & \multicolumn{3}{c}{ Jumlah Daun (Helai) } \\
\cline { 2 - 7 } & 3 MST & $\mathbf{5 ~ M S T}$ & $\mathbf{7 ~ M S T}$ & $\mathbf{3 ~ M S T}$ & $\mathbf{5 ~ M S T}$ & $\mathbf{7 ~ M S T}$ \\
\hline Kontrol & $13,88 \mathrm{~b}$ & $14,90 \mathrm{~b}$ & $15,50 \mathrm{~b}$ & $24,67 \mathrm{~b}$ & $30,45 \mathrm{~b}$ & $31,77 \mathrm{~b}$ \\
$\mathbf{5 0}$ gr Kompos/Polybag & $24,93 \mathrm{a}$ & $27,70 \mathrm{a}$ & $29,00 \mathrm{a}$ & $33,89 \mathrm{a}$ & $36,00 \mathrm{a}$ & $37,40 \mathrm{a}$ \\
$\mathbf{1 0 0}$ gr Kompos/Polybag & $21,59 \mathrm{ab}$ & $23,48 \mathrm{ab}$ & $24,22 \mathrm{ab}$ & $32,33 \mathrm{a}$ & $33,33 \mathrm{ab}$ & $34,40 \mathrm{ab}$ \\
\hline KK & $53,13 \%$ & $99,04 \%$ & $107,63 \%$ & $1,51 \%$ & $1,31 \%$ & $2,61 \%$ \\
\hline
\end{tabular}

Keterangan: Angka pada kolom yang diikuti huruf yang berbeda pada faktor perlakuan yang sama menunjukkan pengaruh nyata pada uji BNT $5 \%$; P0: 0 gr/tanaman, P1: 50 gr/tanaman, P2:100 gr/tanaman 
Agritrop, Vol. 18 (1): 51 - 59

Tabel 2. Rerata Bobot Segar dan Bobot Keringangin Umbi Bawang Merah (gr) Pengamatan 9 MST

\begin{tabular}{ccc}
\hline \multirow{2}{*}{ Perlakuan } & \multicolumn{2}{c}{ Parameter Pengamatan } \\
\cline { 2 - 3 } & $\begin{array}{c}\text { Bobot Segar Umbi (gr) } \\
\text { Bobot Keriangangin Umbi } \\
\text { (gr) }\end{array}$ \\
\hline Kontrol & $18,83 \mathrm{~b}$ & $8,72 \mathrm{~b}$ \\
$\mathbf{5 0}$ gr Kompos/Polybag & $20,39 \mathrm{ab}$ & $10,16 \mathrm{ab}$ \\
$\mathbf{1 0 0}$ gr Kompos/Polybag & $23,61 \mathrm{a}$ & $11,72 \mathrm{a}$ \\
\hline KK & $6,57 \%$ & $3,45 \%$ \\
\hline
\end{tabular}

Keterangan: Angka pada kolom yang sama yang diikuti huruf yang berbeda pada faktor perlakuan yang sama menunjukkan pengaruh nyata pada uji BNT 5\%; P0: 0 gr/tanaman, P1: 50 gr/tanaman, P2:100 gr/tanaman.

\section{KESIMPULAN}

Berdasarkan hasil analisis dan pembahasan yang telah dilakukan dapat disimpulkan bahwa pemberian kompos berbahan dasar limbah rumah tanggah yang menggunakan aktivator MOL dan EM4 memberikan pengaruh nyata terhadap pertumbuhan dan produksi bawang merah yang terbaik adalah 50 gr kompos/polybag yakni pada parameter tinggi tanaman dan jumlah daun, dan 100 gr kompos/polybag pada parameter bobot segar umbi dan bobot keringangin umbi.

\section{DAFTAR PUSTAKA}

Badan Pusat Statistik (BPS). 2016. http://www.bps.go.id. Produksi, Luas Panen dan Produktivitas Sayuran di Indonesia. Diakses 25 Agustus 2019.

Cahaya A., \& Nugroho D. (2008). Pembuatan Kompos dengan Mnggunakan Limbah Padat Organik (Sampah Sayuran dan Ampas Tebu). e-Jurnal Jurusan Teknik Kimia, Fakultas Teknik, Universitas Diponegoro.

Djuarnani, N., Kristian, dan Setiawan, B.S. 2005. Cara Cepat Membuat Kompos, Agromedia Pustaka, Jakarta.

Ekawandani N. \& Kusuma A.A., 2018. Pengomposan Sampah Organik (Kubis Dan Kulit Pisang) Dengan Menggunakan EM4. Tedc Vol. 12 (1).

Elisabeth D. W., Santosa M., dan Herlina N. (2012). Pengrauh Pemberian Berbagai Komposisi Bahan Organik Pada Pertumbuhan dan Hasil Tanaman Bawang Merah (Allium ascalonicum L). Karya Ilmiah: Jurusan Budidaya Pertanian. Fakultas Pertanian-UB.

Ersa, Purwati. 2018. Pengaruh Media Tanam dan Pupuk Organik Cair Terhadap Pertumbuhan dan Produksi Bawang Merah (Allium ascalonicum L.). Skripsi. Fakultas Pertanian, Universitas Lampung. Bandar Lampung.

Isroi, 2010. Kompos jerami untuk solusi kebutuhan pupuk petani murah mudah cepat. 
Agritrop, Vol. 18 (1): 51 - 59

Kusuma A. Ahmad, Kardhinata H, E., dan Bangun K. M. 2013. Adaptasi Beberapa Varietas Bawang Merah (Allium ascalonicum L.) pada Dataran Rendah dengan Pemberian Pupuk Kandang dan NPK. Jurnal Online Agroekoteknologi 1:4.

Matenggomena M. Faesal. 2013. Agroinovasi. Badan Litbang Pertanian, Sinar Tani: 17-23 April 2013, No.3503.

Mukhlis, P. dan Anggorowati D. 2011. Pengaruh berbagai jenis mikroorganisme lokal (MOL) terhadap pertumbuhan dan hasil bawang merah pada tanah aluvial. Fakultas Pertanian Universitas Tanjungpura. Pontianak.

Mulyono. (2014). Membuat MOL dan Kompos dari Sampah Rumah Tangga. Agromedia Pustaka. Jakarta.

Nizar, M. 2011. Pengaruh beberapa jenis bahan organik terhadap pertumbuhan dan hasil padi dengan metode SRI. (http://faperta.unand.ac.id/solum/v08-1-03-p19-26.pdf).

Poerwowidodo, M. (1992). Telaah Kesuburan Tanah. Angkasa Bandung.

Salisbury F. B., \& Ross. (1995). Fisiologi Tumbuhan. ITB. Bandung.

Soenandar M. \& Tjachjono H. R. (2012). Membuat Petisida Nabati. P.T AgroMedia Pustaka. Jakarta.

Sulistyaningsih N., Wahyuni W., \& Mudjiharjati A. (2007). Potensi Pseudomonas aeruginase Dalam Ekstrak Pupuk Kompos Limbah Sayuran Sebagai Biofertilizer Tembakau Cerutu. Jurnal Pertanian Mapeta, 10 (1) : 42-50.

Sumarni, N., R. Rosliani, R. S. Basuki dan Y. Hilman. 2012. Pengaruh varietas, tanah, status Ktanah dan dosis pupuk kalium terhadap pertumbuhan hasil umbi, dan serapan hara $\mathrm{K}$ tanaman bawang merah. J. Hort.22 (3): 233-241.

Susanti Diana S. 2015. Pemberian Berbagai Jenis Kompos Pada Pertumbuhan Dan Hasil Tanaman Bawang Merah (Allium ascalonicum L) Di Kabupaten Enrekang. Agricola, Vol 5 (1), 61-69.

Susanto, R. 2002. Penerapan Pertanian Organik. Kanisius. Yogyakarta.

Tuhuteru S. 2016. Pengaruh Plant Growth Promoting Rhizobacteria (PGPR) Terhadap Pertumbuhan dan Hasil Tiga Kultivar Bawang Merah Di Lahan Pasir Pantai. Tesis. Fakultas Pertanian, Universitas Gadjah Mada. Yogyakarta.

Widawati, S., Suliasih dan Syaifudin. 2002. Pengaruh introduksi kompos plus terhadap produksi bobot kering daun kumis kucing (Orthosiphon aristatus Bl. Miq) pada tiga macam media tanah. J. Biol. Indonesia 3(3): 245-253.

Yetti, Y. \& Elitta, E. (2008). Penggunaan Pupuk Organik dan KCL Pada Tanaman Bawang Merah (Allium ascalonicum L). SAGU. 7 (1) : 113-18.

Yuliarta, B. 2014. Pengaruh biourine sapi dan berbagai dosis pupuk NPK terhadap pertumbuhan dan hasil tanaman selada krop (Lactuca sativa L). Jurnal Produksi Tanaman 1(6):1-10.

Yusuf, T., 2010. Pemupukan dan Penyemprotan Lewat Daun. Tohari Yusuf's. Pertanian Blog. http://tohariyusuf.wordpress.com/. 